\title{
Una realidad aparte
}

\section{Mundos mediáticos y experiencias cinematográficas en las culturas locales}

\section{HÉCTOR GOMEZ*}

\begin{abstract}
Resumen. El presente trabajo es parte de una investigactón mayor que pretende explorar los antecedentes bistóticos de como fue llegando la globalizacion a algunas culturas locales, $y$ algunas de las transformaciones culturales que en ellas se dieron a través de la experiencia cultural que algunos de los babitantes de la ciudad de Leon, Guanajuato, tuvieron con el cine local cuando fueron adolescentes en un periodo que va de 1955 a 1975, etapa de cambios significativos a nivel mundial, nacional y local por la llegada de una nueva fase de la internacionalización. Realizada por medio de bistorias de vida temáticas, la investigacion pretendía ver cómo la experiencia con el cine era un fenomeno complejo donde se ponian en tensión las matrices bistóricas de la cultura local y las matrices culturales que llegaban del exterior, y que se pueden apreciar a través de los mundos sentimentales y cognitivos que se comenzaron a presentar en los puiblicos de cine y por la integración de la prictica de ir al cine dentro de las rutinas y ritos sociales leoneses.
\end{abstract}

\section{Perspectivas}

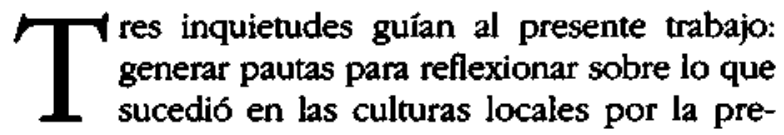
sencia de los medios de comunicación en el país; abordarlo desde el caso específico del cine; y explorar lo anterior, pero desde la perspectiva de algunos sujetos sociales.

- Especialista en estudios socioculturales, pensamiento complejo, ciencias cognitivas. Universidad lberoamericana, Campus León. Correo electronico: hector.gomezoleon.uia.mx 
Respecto a lo primero, nos parece que es sumamente pertinente abordar las culturas locales por dos razones que se pueden ver por sendas perspectivas. La primera, ya que en tiempos de lo global, es en esos entornos donde se encuentra la contraparte de las transformaciones culturales que se están dando. Lo local es uno de los ejes del desarrollo de la globalización (Robertson, 1997). La segunda, porque vistos desde lo local, los procesos globales han sido uno de los artífices de las principales transformaciones que se han dado a lo largo del siglo xx en las culturas locales, primero mediante la internacionalización, la modernización y actualmente con la globalización (Harvey, 1993; Featherstone, 1993). El punto intermedio permite observar la "nebulosa" aura de lo global, así como la borrosidad constitutiva de la cultura, conformada por una diversidad de manifestaciones culturales que tienen en su base una configuración y trayectoria particular (Hannerz, 1997).

Acerca de lo segundo, el caso del cine, es curioso cómo en muchos de los tratados sobre el mundo contemporáneo o los desarrollos actuales de las tecnologías de comunicación $\mathrm{e}$ información, el cine brilla por su ausencia cuando pensamos, es un elemento sumamente importante en la cultura del mundo hoy día, pues en muchas de las travesías de la industria del entretenimiento, y de la economía global, la industria del cine es una de las más importantes. Incluso, se puede percibir su vínculo con las estéticas, las narrativas que emanan de los nuevos mundos mediáticos (Darley, 2002), así como en el modo en el que se están redefiniendo las maneras de acceder a las nuevas tecnologías de comunicación y que propicia una serie de reconsideraciones sobre los entornos de la recepción (Livingstone, 2002) y las habilidades necesarias para acceder a los nuevos medios de comunicación (Livingstone, 2003; Lievrouw y Livingstone, 2002). Pero, tambien, el cine tiene una historia con muchas culturas locales a lo largo del siglo $\mathrm{xx}$, $\mathrm{y}$ en su vínculo se puede ver la manera como las culturas locales se transformaron.

Finalmente, la inquietud de abordar estos fenómenos desde la experiencia de los sujetos sociales se debe a que sus biografias, sus trayectorias, constituyen una de las vías por donde es posible observar el paso de una sociedad cada vez más orgánica que estructural debido a la pérdida de sus centros tradicionales de organización de lo social (Maffesoli, 1993), actuando más a través de flujos, mediaciones, e interconexiones, al configurar y ampliar sus realidades sociales y culturales, y al adquirir y desintegrar formas para vivir lo social (Appadurai, 2001; Maffesoli, 2004).

De esta forma, lo que queremos explorar en el presente artículo se refiere a la manera en la que algunos sujetos sociales recuerdan la importancia del cine para sus vidas, y en particular, por qué asistian a las salas de cine, y el mundo subjetivo que les brindaba y el estilo de vida que se les abría por delante.

El punto de partida es una investigación que realizamos en la ciudad 
de León, Guanajuato, ${ }^{1}$ para observar sus transformaciones culturales a partir de la segunda mitad del siglo xx. Una serie de preguntas guiaron la investigación. La primera era acerca de qué es una cultura local en tiempos de la globalización. Otra era acerca de cómo entró lo global a las culturas locales, y el papel que han desempeñado los medios de comunicación en ese proceso. Ante ello, se decidió introducir el factor del tiempo para ver el proceso histórico no sólo de cómo fue entrando el mundo global en lo local, sino las transformaciones culturales que se dieron en las culturas locales. Así, la investigación no se basó en el tiempo actual, sino en el pasado reciente, en una etapa en donde se dieron una serie de procesos varios que coincidieron y propiciaron las alteraciones en lo local. Esa etapa fue a finales de los cincuenta y hasta mediados de los setenta, donde a nivel mundial inició una nueva fase del sistema mundial y a nivel nacional se vivieron momentos de modernización e internacionalización con el comienzo del "milagro mexicano" que propiciaron una nueva dinámica en algunas ciudades del país. Pensamos que el medio de comunicación que nos podía ayudar a responder las dos preguntas anteriores, desde la perspectiva histórica, era el cine, no sólo eso, también creímos que la mejor manera de abordar esas preguntas era a través de la experiencia cultural de los hombres y las mujeres que vivieron de jóvenes esa etapa en la ciudad de León, Guanajuato, pues mediante sus experiencias culturales se pueden encontrar otras vías de la morfogénesis social (Navarro, 1995), las formas orgánicas de la misma sociedad y sus procesos de transformación (Navarro, 1994) que se propician por la reacción de la configuración histórica y cultural de lo local con la llegada de lo global (Tufte y Jacks, 1998). Es por ello que una de las preguntas que se intentó responder fue: ¿Cuál fue la experiencia cultural con el cine de algunos jóvenes en la ciudad de León, Guanajuato?

La investigación es mucho más amplia de lo que aquí se presenta, y partiendo desde una postura epistemologica que proviene en parte del construccionismo social y de la sociología reflexiva de segundo orden (Gómez Vargas, 2003), se optó por la metodología cualitativa siguiendo algunos pasos de la "teoría fundada" (Strauss y Corbin, 1990), y de los procedimientos metodológicos y tecnológicos de la historia oral (Thompson, 1993; 1988) para llevar a cabo una serie de historias de vida temáticas (Aceves, 1998) que se realizaron a lo largo del año 2000 en la ciudad de León. La historia oral no sólo estaba en la línea de la perspectiva epistemológica, ontológica y metodológica asumida ${ }^{2}$ (Castro, 1996), sino

- La investigación mencionada es la que se realizo para optar por el Doctorado en Ciencias Sociales de la Universidad de Colima, y cuyo título es: "Todas las mañanas del mundo. Transformaciones en la cultura local y medios de comunicacion. La experiencia de las mujeres con el cine en la ciudad de León, Guanajuato (1955-1975)".

2 Es decir, una perspectiva epistemológica más subjetiva, una ontología que concibe a la realidad como un universo de sentidos que puede ser interpretada, y una metodologia cualitativa. 
que también, nos permitía cubrir una seria carencia de información histórica y estadística acerca de la ciudad de León, sus habitantes y el cine, en la época estudiada.

Se asumio que no era un estudio que tomaba la experiencia de diversos grupos sociales, sino de un grupo muy específico por medio del cual era posible ver los trazados hegemónicos de la configuración de la cultura leonesa; tomando en cuenta el factor clasista de la experiencia de ir al cine, se optó por la clase media, y más bien apuntamos hacia las diferencias que se daban en relación al género y a la generación. ${ }^{3}$ A través de la dimensión del género es posible ver la gran complejidad de la experiencia cinematográfica, a la vez homogénea y diversa, así como la impronta de la cultura local que actuaba en ellos a través de los modelos de ser hombre y mujer que ahí se habian configurado. Las diferencias generacionales, por su parte, nos darian pistas de las transformaciones que se daban en la cultura local, en el mundo, y que se manifestaban en los cambios de la vida en la ciudad y en las nuevas subjetividades que iban apareciendo.

El presente trabajo se desarrolla en tres secciones. En la primera abordamos el tema de los mundos mediáticos que emanan de los medios de comunicación para señalar cómo éstos han impactado en las interacciones sociales, aunque, desde la perspectiva de la vivencia de las personas, ello implica tanto una "experiencia" como una "biografia" mediắtica. A partir de eso, reflexionamos acerca de lo que ha sido la experiencia del cine en algunas culturas locales. En la segunda parte, abordamos algunos elementos del cine: la importancia de lo visual dentro de las culturas contemporáneas, donde al cine se le puede ver no sólo como un mero entretenimiento de catarsis o lúdico, sino como un aparato cognitivo y cultural. Finalmente, en la tercera sección abordamos la experiencia cultural de algunos hombres y mujeres con el cine, y particularmente las representaciones que emanan de lo que para ellos era ir al cine, y lo que el cine les dejaba en sus vidas.

\section{Mundos mediáticos. Comunicación, medios de comunicación}

En los tiempos que corren, existe un reconocimiento creciente de que el desarrollo histórico de los medios de comunicación ha sido parte de la manera en la que se ha dado la vida simbólica, cultural, de la sociedad moderna. Su aparición y desarrollo tienen una relación estrecha con

3 La selección de informantes se realizó tomando en consideración los principios básicos de las historias de vida temática, de la decisión de trabajar con personas, hombres y mujeres, pertenecientes a la clase media leonesa, y que fueron adolescentes entre 1955 a 1975, aproximadamente. Se contó al final con un total de 18 entrevistas, 9 de hombres y 9 de mujeres, a los cuales se les asignó una clave (LE de León, $\mathrm{H}$ para los hombres y $\mathrm{M}$ para las mujeres) y un número asignando, el primero al hombre o mujer de mayor edad hasta el o la más joven. 
factores políticos y económicos que harán propicia su emengencia, uso y diseminación, así como una creciente centralidad y racionalidad comunicacional en los últimos tiempos. También, propiciarán alteraciones en las percepciones y experiencias sociales de los individuos, que se irán modificando a lo largo del tiempo. El quehacer de los medios de comunicación en las sociedades modernas hará más visible su dimensión cultural y agregará otros elementos para la comprensión de la modernidad, pues no sólo es un factor de la nueva "semiosis social" al facilitar y relacionarse con las condiciones y dinámicas tanto económicas como políticas, sino por las estructuras, prácticas y diversos contenidos que lo constituyen.

Es por ello que varios autores proponen ver a las sociedades modernas desde una dimensión de lo simbólico, es decir, a partir del modo como se han producido, circulado y consumido formas simbólicas en un contexto histórico y social, para poder abordar el proceso de mediatización de la cultura que se fue desarrollando a la par de los cambios y reorganizaciones en el orden de lo político y de lo económico.

Un factor fundamental para comprender los procesos crecientes de lo mediático en las sociedades contemporáneas es la forma en la que los medios de comunicación se distinguen de las anteriores maneras de comunicación. Por eiemplo, John B. Thompson parte desde la naturaleza y los usos de los medios de comunicación y los concibe como "un tipo diferenciado de actividad social que implica la producción, transmisión y recepción de formas simbólicas y que compromete la materialización de recursos varios" (1998: 36), y propone que los medios de comunicación han propiciado tres modificaciones importantes: la aparición de nuevas redes de transmisión de información; nuevas formas de acción, interacción y relación; así como nuevas pautas de interacción a lo largo del tiempo y del espacio, que tendrán diferentes modos de desarrollarse de acuerdo con los tipos de interacción social: cara a cara, mediática, cuasi mediática.

Desde esa perspectiva, una de las transformaciones más importantes introducidas por los medios de comunicación se refiere a la manera como permitieron traspasar las fronteras de la relación cara a cara y reordenaron las dimensiones espaciales y temporales de la organización social. Los medios de comunicación propiciaron la separación espacial y temporal, donde la distancia espacial dejo de requerir "distancia" temporal y generó la emergencia de la simultaneidad desespacializada (1998: 53), y con ello el mundo se amplio y se hizo presente, global. Es por eso que las alteraciones espaciales y temporales que surgen con la presencia de los medios de comunicación modifican no sólo un nuevo tipo de interacción con otras personas y con el mundo, sino la misma experiencia de las personas acerca de su vida, la vida social, y su visión sobre el pasado.

Además, Thompson habla de la creciente "experiencia mediática"; es decir, de "nuestra percepción de que el mundo existe más allá de la esfera de nuestra experiencia personal y de que la percepción de nuestro 
lugar en este mundo está cada vez más mediatizada por las formas simbólicas" (1998: 56). La experiencia mediática propiciará modificaciones sobre la percepción de la distancia; en otras palabras, hará que las barreras de las distancias se debiliten, y que con ello el mundo parezca tornarse otro, más cercano y cognoscible; así, la vida diaria adquirirá otros ritmos, como una socialidad mediática, es decir, la alteración de los sentimientos de pertenencia de los individuos a grupos o comunidades, no sólo por compartir una historia que se da en un espacio común, sino porque ahora esa historia y ese espacio común y compartido se da a través de los medios de comunicación (1998: 57). Con respecto a las alteraciones de la visión del pasado, Thompson menciona que se darấ una "historicidad mediática", es decir, que la percepción del pasado y las maneras como afecta a la vida de las personas irá dependiendo cada vez más de una creciente reserva, y presencia, de formas simbólicas.

Entonces, la acción de los medios de comunicación puede verse como un factor que altera las dimensiones espaciales y temporales, pero que está en estrecha relación con la forma en la que esto se realiza y materializa en entornos sociales concretos, que a su vez tendrán e implantarán algunas modificaciones que alterarán a ambas dimensiones. Lo que sucede en las ciudades y en las subjetividades de sus habitantes es parte de ello. Las ciudades han sido parte de las transformaciones y la zona de cruce por el tránsito de diversos tipos de ciudades que se han dado cita y han ido conviviendo simultáneamente. Los medios de comunicación se han instalado y convertido en parte integrante de muchos procesos de la vida cotidiana. En ese sentido, son parte de la vida social y se distribuyen espacial y temporalmente dentro de ella. Asimismo, la presencia y desarrollo de los medios de comunicación es una trayectoria donde no sólo se modifica como tecnología, como un sistema de producción, distribución y consumo de formas simbólicas, sino que transforma sucesivamente su relación con estructuras varias, formas sociales y subjetividades, por lo que tiene una historicidad de su desarrollo y de su mediación con las sociedades.

El desarrollo de los medios de comunicación, así como de los entornos urbanos en donde se inscriben y de las nuevas socialidades, invitan a pensar complejamente en la presencia y acción de los medios de comunicación en las sociedades a partir de las emergencias de las nuevas realidades sociales que se abren (Johnson, 2003), y con ello aparece una visión de diferentes niveles, $u$ ordenes, de interacción social a partir de la presencia de diversos tipos de tecnología empleada para la comunicación, pues generan un entorno altamente complejo ante el hecho de que los tres tipos de interacciones sociales pueden estar presentes en cada contexto social e histórico, de diferentes modos, en distintas manifestaciones e intersticios de una realidad social, aunque algunas sean predominantes de las formas generales y generalizantes de comunicación (Lull, 2000). 
La visión sobre el accionar de los medios de comunicación dentro de los entornos de las culturas locales, en tiempos de transformaciones culturales como las que se dieron en el siglo $\mathrm{xx}$, puede centrase en el cine por varias pazones.

El cine conecta y hace visible los mundos varios que se han dado, es una trayectoria histórica y cultural por donde se pueden observar las transformaciones culturales que hoy están en el centro del huracán de la vida social. Por ello pensamos que la experiencia de la llegada y presencia del cine a distintas partes del mundo implico procesos y experiencias similares, aunque cargadas por los contextos particulares de las diferentes culturas.

El cine es un medio de comunicación de segundo orden donde la relación social es mediada por un artefacto cultural, en un contexto histórico y social previamente configurado, e implicó la conformación de una "cuasiinteracción mediada", lo cual propició "un cierto tipo de situación social en la que los individuos se vinculan en un proceso de comunicación e intercambio simbólico. También crea tipos distintivos de relación interpersonal, lazos sociales e intimidad (lo que yo llamo intimidad no recíproca a distancia)" (Thompson, 2000: 231). Dentro de estas reflexiones, Thompson dirá que una de las consecuencias de este nuevo tipo de interacción fue el efecto en la naturaleza de lo "público", y en la manera en que los individuos y los eventos eran hechos "visibles" para otros. El desarrollo de los medios de comunicación creo "nuevas formas de lo público muy distintas a la copresencia tradicional. Su rasgo clave es que, con la presencia de la disponibilidad que posibilitan los medios, el carácter público de los individuos, las acciones o los eventos ya no quedan ligados a la condición de compartir una localidad" (2000: 233).

Sin embargo, en el contexto de las culturas locales, las comunicaciones "cuasi mediadas" o de segundo orden, como es el caso del cine, se puede ver a la comunicación como parte de la vida ritual de esas sociedades. Tufte y Stegg sentalan que la idea de la comunicación no es nueva en los estudios de la comunicación en donde existe un énfasis que se pone más en el ritual que en la transmisión. Mencionan la obra de James Carey quien señalará que el papel de la comunicación desde el ritual no es la información sino la confirmación, es decir, más que cambiar, representa "las creencias compartidas por la sociedad y juega un papel en una confirmación continua de un orden culcural y sociedad fundamental" (Steeg y Tufte, 2001: 20), y al ser la comunicación una forma simbólica, en el ritual crea representaciones "de $e^{n}$ "para" la realidad. Si bien Carey no analiza el caso en ningún medio de comunicación, Steeg y Tufte dirán que se pueden derivar dos puntos importantes: 
Primero, la comunicación sirve para definir, mantener y transformar la realidad hacia un orden comprensible que constantemente se comenta en la comunicación. Segundo, y como consecuencia, la comunicación está en relación directa con la realidad. Entonces, los rituales no son actividades que estén apartadas por completo de la realidad. Además, la comunicación como ritual está involucrada constantemente al definir y modificar la realidad [Steeg y Tufte, 2001: 21].

También mencionan el caso de Roger Silverstone (1996), que si bien no da una definición de ritual, señala que es una parte importante del papel de la televisión en la vida cotidiana, y que representa "suspensiones momentáneas" de la cotidianeidad, y pese a ello, la televisión toma a la cotidianeidad como objeto de reflexión continua, por lo que no está separada. Algo similar realiza Klaus Bruhn Jensen cuando habla del "tiempo dentro" y del "tiempo fuera", donde la acción de los medios de comunicación se da dentro del segundo, pero que son morrentos para observar al primero (Jensen, 1997). La visión que dan Silverstone y Jensen iría en el sentido de que los rituales de la comunicación se dan porque está de por medio la atención a los contenidos que transmiten los medios de comunicación, pero que también se puede dar el caso donde el contenido no es parte central, sino secundaria, y que más bien es un "elemento necesario en la acción continua y en la definición en conjunto de la situación" (2001: 24), por lo que los medios juegan un papel importante en los mismos rituales diarios.

Este último punto, nos parece que es una observación sumamente importante para el caso del cine, pues la experiencia de las personas en una sala implica tanto un ritual "como suspension", en el sentido de que se vive de manera individual, como un hecho extraordinario, ocasional, ante una realidad alternativa donde se da una relación por vía del contenido que se proyecta en la pantalla, que a su vez le permite a las personas observar su cotidianeidad, su vida interior y su vida social, pero que además se puede dar como un ritual de "integración", donde se vive dentro dé lo ordinario un acto social que ratifica una realidad y una posición social. Sin embargo, habría que reconocer que al ser un ritual de "integración", está normado bajo reglas que son más amplias que las mismas que se dan en el cine, y que se ponen en movimiento, en acción, $y$ se distribuyen a lo largo de los momentos rituales donde se incluye el cine, y que es ahí en donde podemos observar las improntas de la cultura de los grupos sociales que asisten a él. Asimismo, el cine le agrega a esos ritos algunos elementos que sólo ahí, y en espacios similares, se podian realizar, donde se podía intensificar la integración; es decir, al ser un punto de encuentro de grupos sociales, se convierte en un espacio por excelencia del reconocimiento. Ambas son realidades que se dan en la experiencia de ir al cine, con algunas alteraciones a lo 
largo del tiempo, 4 pero que conforman parte de la misma experiencia que se genera al estar en una interacción cuasi mediada: no sólo es en lo individual, y no sólo genera una nueva visibilidad de lo público, sino que además ratifica la dimensión social y el orden pre existente.

También, el cine puede ser visto como un aparato cognitivo y cultural, por medio del cual se distribuye un saber comunicativo, cultural y social entre las personas y los grupos sociales. En términos de las ciencias cognitivas, el cine puede ser visto como un artefacto mediador que distribuye, de manera general y diferenciada, un saber cognitivo de su cultura, su historia, y genera una experiencia que se desarrolla a lo largo del tiempo, bajo los límites de interpretación y de acción de los mismos grupos sociales y las reglas de la vida social, igualmente permanentes y cambiantes (Cole y Engeström, 2001). Al ser un artefacto mediador de la cultura de un grupo, el cine socializa de manera amplia y diferenciada un conocimiento social.

El cine, entonces, al verse como un artefacto cultural, puede entenderse como un elemento estructurador de "la estructura de sentimiento" de las personas, la cual los integra a una tradición a través de una serie de principios, normas, y representaciones, que los abre a una dinámica social y cultural, en desarrollo y transformación, y que al mismo tiempo qué une a grupos de generaciones anteriores y posteriores, los hace diferentes.

El mundo del cine es amplio, contradictorio, un elemento donde principios dialógicos antagónicos se encuentran; que al mismo tiempo que selecciona realidades para nombrarlas y mostrarlas, elimina y deja en el espacio de la no visibilidad otras realidades; un espacio que desborda los mismos límites de la pantalla, de la película, de la sala de cine, al mismo espectador, para dar cuenta a los mundos exteriores, pero que simultáneamente los invoca cuando la pantalla, la película, la sala y el espectador se encuentran. Todo ello en espacios sociales concretos, dentro de entornos sociales, cotidianos e históricos, y en relación a sujetos individuales, sociales e historicos concretos.

\section{La vida a traves de las imagenes}

El cine ha sido parte de un proceso civilizatorio para la conformación de una percepción de la realidad y una manera de vivir en el mundo. Su presencia en el mundo contemporáneo se remite a lo realizado a partir de

- Habría que reconocer que las reflexiones se elaboran a partir del hecho de que la práctica del cine implica la asistencia a una sala cinematografica, y que con el tiempo eso se ha alterado, pues el tipo de construcciones cinematograficas se han alterado a lo largo del tiempo, así como su ubicación espacial dentro de la ciudad. Asimismo, se ha alterado debido a su presencia en otros medios de registro y vías de consumo, como sería el caso de la televisión, el videocassette, $y$, más recientemente, el DVD. 
su aparición, su consolidación y desarrollo a lo largo del siglo xx, ya que permitió iniciar un tipo de exploración, creación y percepción de un mundo que comenzaba una nueva fase histórica de crecimiento y expansión de la internacionalización, donde las formas simbólicas eran cada vez más la base de la vida social y subjetiva, conformando experiencias sociales, modelos, patrones y rutas de vida, una matriz cultural, un capital simbólico y cognitivo, que sería la antesala de lo que más adelante la televisión y la realidad digital desarrollarían.

Al ser parte central de la semiósfera de la vida moderna (Lotman 1996: 24), el cine ha sido parte de una matriz cultural y cognitiva más amplia que se fue desarrollando junto con la presencia y acción de otras industrias audiovisuales, es decir, un entorno y un ambiente como un gran sistema conformado por la acción y presencia de universos varios de signos que envuelven, circulan y cruzan la vida social y subjetiva del hombre moderno.

El mundo imaginario se tornó realidad exterior e interior, forma de vida y diseño social, un entorno psicosocial que integró al individuo a su entorno cotidiano, y que le permitió una vida emocional mediante una serie de modelos en permanente movimiento y transformación. Es decir, la industria del cine permitió una nueva integración de la vida anímica, imaginaria y simbólica del hombre con su realidad cotidiana mediante los diseños y universos simbólicos que ella, así como la industria audiovisual en general, favorecían como nuevos entornos materiales y epistémicos para comprender $\mathrm{y}$ acceder a las nuevas realidades sociales.

Asimismo, el cine no sólo ha sido un universo que se manifiesta y se experimenta en el'mundo de lo imaginario, sino que cobra cuerpo en modos de vida y formas de ser. Ésa ha sido otra de las dimensiones de trabajo de la iconósfera y que se ha dado mediante la conformación de una cultura colectiva, a través de la acción de las industrias culturales de las masas (Morín, 1966: 110), para la conformación de una nueva experiencia cultural donde el cine ha tenido un papel importante, ya que ha sido uno de los'elementos y de las interfases del universo audiovisual y simb6lico de un mundo que cada vez se ha tornado más globalizado. A lo largo del tiempo, en muchos lugares del mundo, Hollywood se constituyó no sólo en el cimiento del sector audiovisual de la cultura estadounidense y mundial, alrededor del cual la presencia de nuevos medios de comunicación electrónica se desarrollaron, sino que comenzó a generar tanto las bases empresariales, comerciales e industriales, como todo un universo del imaginario y las mitologias de la cultura popular internacional que se han difundido y hecho parte de la cultura mundial (Gitlin, 2001), y que además de ser uno de los pilares del imperialismo estadounidense, lo es de los nuevos conglomerados industriales, económicos y culturales de la globalización (Sinclair, 2000). 


\section{Los privilegios de la vista}

Todo indica que hay una gran tendencia a buscar la experiencia cinematográfica alrededor de las imágenes del cine y su relación directa e individual con ellas. Sin embargo, si el mundo cognitivo y emocional que propicia el cine se ha desarrollado alrededor de generar una experiencia, un cúmulo de representaciones sociales tanto del mundo exterior, cercano y lejano, así como del mundo íntimo, subjetivo, la experiencia cinematográfica no se limita únicamente a lo que sucede cuando la gente está frente a la pantalla, ni en relación exclusiva con lo que sucede con la sucesión de imágenes, sino, también, en los contextos varios donde las sujetos viven su vida y donde la presencia de ese universo simbolico del cine se instala.

Además de considerar el proceso que se da por la relación de las imágenes que se proyectan en la pantalla cinematográfica, es necesario no perder de vista la conformación de la mirada por parte de los públi$\cos$, que es un proceso más amplio, histórica y culturalmente, que tanto está en relación con un orden social, como con un tipo de subjetividad, y es una manera de organizar el mundo cotidiano, de construir socialmente una realidad. La mirada se convierte en un tema de especial interés: en ella se concentran los mundos perceptivos, cognitivos y emotivos a partir de los cuales se conforma un tipo de realidad social y la manera como los sujetos la habitan. La mirada ha sido desde los inicios de los tiempos un aparato cognitivo y una mediación con las realidades múltiples de las distintas sociedades humanas.

El cine puede ser visto a partir de dos perspectivas intimamente relacionadas desde el acto de mirar películas. Por un lado, se trata de una propuesta de mirada que representó casi desde sus inicios una nueva manera de ser, conocer y organizar tanto el mundo social como el mundo subjetivo. Pero esta forma de mirar no sólo se refiere a lo que la misma pantalla ofrece a la subjetividad del espectador, sino a un entorno de cambios de modos de vida, de matrices culturales y constructos históricos que se comenzaban a dar desde la segunda mitad del siglo. XX. Representa un acto cognitivo de la realidad y un surtidor de matrices culturales, tanto de las ya existentes, tradicionales, como de aquéllas que comienzan, que hablan de transformaciones o de nuevas realidades.

El cine representa una misma matriz cultural a partir de la cual el espectador ha conformado su mirada, un proceso cognitivo y emocional distribuido en sus contextos, tanto particulares. y sociales, como culturales e históricos, desde donde ha mirado y ha conformado una forma de mirar. El cine es una mirada cultural que tanto refuerza el mundo social construido, como lo pone en movimiento, en reorganizacion. Keneth Gergen (1997) habla del yo saturado, una condición que relaciona con la manera como el mundo posmoderno genera distintos discursos, realida- 
des, experiencias que están presentes en la vida cotidiana de nuestros tiempos e implican distintas propuestas de identidades del yo de las personas, con lo cual la realidad externa e interna se ve no sólo relativizada, pues cada propuesta contiene su propia dimensión de veracidad y verdad, sino también saturada. Este contexto de la saturación del yo es un proceso histórico donde la visión romántica del yo se va difuminando, erosionando, mientras se conforma una serie de nuevas visiones del yo de la vida moderna y posmoderna.

\section{Las alas del deseo}

Al parecer, no sólo hay un vínculo del teatro con el cine en cuanto que retomó de él una serie de elementos narrativos y de representación, también lo hay en la manera como se conformó un público y los vínculos que se establecieron para el consumo de una serie de productos culturales y la conformación de una experiencia social y cultural.

Todo indica que el fenómeno de los públicos hoy día no se puede comprender sin un proceso histórico de conformación y transformación histórica y cultural, pues en ella se darán algunos de los elementos básicos que hasta hoy los caracterizan, así como los elementos y relaciones que los conforman y se transforman con la llegada de los medios de comunicación y el tipo de experiencias que se propician. De entrada, al público se le relaciona con el espectáculo y posteriormente se le añadirá el consumo.

La experiencia del público de teatro fue la base de algunas de las formas como se ha querido explicar la experiencia con el cine. Durante la primera década del siglo xx, Sigmund Freud escribió un pequeño trabajo sobre los personajes psicopáticos en el teatro que es importante porque sintetiza en mucho la manera como tradicionalmente se ha entendido la función del teatro en el público a partir de la Poética de Aristóteles. Freud expresa que si bien desde los tiempos de Aristóteles se ha considerado que el drama despierta la piedad y el temor, mediante una catarsis de emociones, tambienn se le puede entender porque propicia el acceso a fuentes de placer y goce, y lo relaciona con lo que sucede con lo cómico y con el chiste, como lo había ido reflexionando en La interpretación de los sueños (1984) y El cbiste y su relactón con el inconsciente (1981). La visión de la catarsis emocional es una de las concepciones más antiguas, así como una de las que más prevalecen a lo largo del siglo $\mathrm{xx}$. Tom Lutz (2001) en su historia cultural sobre el llanto lo deja ver cuando hace un recorrido histórico sobre la manera en la que se ha entendido y vivido el acto de llorar. Cuando aborda el llanto en el siglo $\mathrm{xx}$, despues de haber recorrido los siglos anteriores, dirá que hay una continuidad de las tendencias originales del llanto, con algunas modificaciones debido a la 
presencia de los discursos que sobre las lágrimas ha invocado y modelado en sus espectadores la industria cinematográfica de Hollywood, ya sea como una experiencia estética o mero entretenimiento, donde el placer y la liberación son dos elementos que buscan los espectadores de cine (2001: 43).

Desde esa perspectiva, el cine se convierte en una máquina psicologi$\mathrm{ca}$, en un surtidor de sueños y deseos. Una tendencia muy fuerte es la de clasificar a los espectadores de cine en función de su actividad o pasividad para desprenderse del mundo de las imágenes que contemplan y los procesos reflexivos que les generan en la vida cotidiana. Uno de los elementos clave para el proceso de identificación y proyección será el star system, las estrellas de cine, pues el vínculo que propicia con el espectador se da en diferentes aspectos y niveles, más allá del contexto inmediato de la película y se manifiesta de diversas maneras (Tudor, 1975: 88) y por lo mismo se convierte tanto en un atractor promocional de las películas, un subtexto de la película que se inscribe como un elemento dramático intertextual por todo el capital simbólico que el actor o la actriz representan, así como todo un universo de películas que se han creado y el espectador ha visto (Dick, 1981: 88), como en un laboratorio psicológico y sociocultural para los mismos espectadores, un mundo que actúa más en la vida emocional que en la racional de sus espectadores.

Algo sobre lo que se comparte en los últimos tiempos se refiere a la importancia de la vida emocional de las personas. A diferencia de la modernidad donde el factor que rige la vida social era la razón, en los tiempos que corren, al individuo y a la colectividad "lo mueven, igualmente, los sentimientos, los afectos, los humores, todas las dimensiones no racionales de lo dado del mundo" (Maffesoli, 2001: 33). El mundo se ha hecho relacional mediante una resignificación de lo individual que lo sume en una colectividad que la "funcionalidad económica o política no ofrece" (2001: 38), y mediante una serie de actos rituales donde se retorna a un tiempo cíclico, se da "la posibilidad de vivir un yo plural, o de superar al yo en una entidad más vasta" (2001: 40).

Por esa razón, mirar al cine implica una mirada que no sólo se da frente a la pantalla y en la sala de cine, sino en contextos más amplios, el de la vida cotidiana de los individuos, las trayectorias históricas individuales y sociales, que tanto conforman la mirada que se pone en juego mientras se mira al cine, como reconfiguran la mirada cultural.

\section{Hasta el fin del mundo}

La experiencia de los públicos con el cine puede tener simultáneamente elementos comunes y diversos, heterogéneos y homogéneos, coincidentes y paralelos. La base es el encuentro de dos realidades que son miradas 
por un sujeto o una colectividad desde su contexto histórico y social, que torna a la mirada en una mirada cultural.

Las memorias de los leoneses que vivieron su adolescencia en las dos primeras décadas del siglo xx ubican su experiencia con el cine como una realidad ya dada y como parte de la vida social de la sociedad leonesa. En ese sentido, hay una continuum desde donde se ve y se vive al cine: por un lado, hay una serie de recuerdos de las salas de cine y el tipo de oferta que se ofrecia, así como de las rutinas, las personas que iban, lo que ahí acontecía. Esto implica una memoria histórica que forma parte de su capital cognitivo sobre su experiencia con el cine, pero también una visión clasista, una ideología desde donde se le experimentaba, vivía y desde donde se le recuerda. Asimismo, significa una serie de conocimientos sociales acerca del hecho de ir al cine, un conocimiento que se conectaba de manera íntima con los contextos y dinámicas que estaban alrededor del cine: su vida cotidiana, sus redes sociales de perte182 nencia, sus mentalidades e ideologías que no se quedaban afuera del cine, sino que ingresaban y estaban presentes. El mundo exterior tomaba como parte de su misma organización cotidiana al cine; es decir, el cine era una rutina social y mucho de lo que se vivía en el interior de él era un reflejo de lo que se vivía en el mundo exterior.

En esos mundos la vivencia que guardan en la memoria los leoneses es que el cine posibilitaba dos experiencias paralelas: por un lado, la posibilidad de reunión, encuentro y socialización; por el otro, la posibilidad de fugarse de su realidad cotidiana. Estas dos posibilidades son expresadas a partir de lo que piensan en el presente del porqué iban al cine, o, incluso, de la importancia del cine para su vida personal o para la ciudad, y que tras su primera impresión sobre lo que ello era o representaba, inmediatamente o a lo largo de las reflexiones va apareciendo un fondo, un horizonte donde cobran mayor significación de la importancia o presencia del cine en sus vidas. Es decir, en algunos casos no hay duda: la persona lo sabe porque lo ha tenido presente a lo largo de su vida; en otros, no tanto, se enuncia una primera imagen, una primera impresión y tras un proceso donde la pone en explicitación narrativa o reflexiva, la imagen o la impresión cobra otra corporeidad y presencia que terminan dudando de si el cine fue algo accesorio, concebido como un entretenimiento o un pasatiempo, para conectarse con algo más amplio de su vida, su visión sobre ella, o sus aspiraciones.

Desde esa perspectiva, entonces, el cine tiene una dimensión de lo social, del modo como ésta se realizaba e incidía en el cine. En este punto, el cine era un agente de socialización que reforzaba la pertenencia a un grupo social, una rutina establecida dentro de la vida familiar, un referente social y cultural para varios grupos de individuos. Una manera de ser del y en el mundo, y es por ello que se vivía con una serie de estereotipos y representaciones que regulaban el comportamiento exter- 
no, la vida pública, mediante normas, códigos y ritos sociales. Pero, por otra parte, tiene que ver más con el mundo subjetivo, con la manera en la que la gente veía una forma de divertirse, y de entretenerse, y que era algo más que el elemento catártico y relajante: era aprender o reforzar una vivencia interna, una aspiración, un ideal, la posibilidad de sentir lo que el mundo exterior no permite o posibilita, un modo de ampliar los horizontes personales e inmediatos. Es por ello que el entretenimiento, la fuga, era algo que se vivía como lo intimo, lo interior y privado, e implicaba la posibilidad de entrar a los terrenos de lo desconocido, lo sombrio, de lo prohibido, de lo que se adquiere únicamente en el sentir, en la imagen que se genera y la acción que impulsa. Un mundo donde las normas y los códigos sociales se relativizan, pero al mismo tiempo se viven a través de las tácticas y estrategias de lo pequeño y lo íntimo. Era el encuentro de mundos varios que tiran por distintas direcciones, cada uno con una propuesta de identidad personal, real e imaginaria, donde a veces entraba lo profundo, como un sueño, y a veces como una ilusión o un modelo a seguir, una identificación que buscaba encontrar maneras de manifestarse.

\section{El surgimiento de una nación}

En las reflexiones que hizo Andrei Tarkosvski sobre el cine en su libro Esculpir el tiempo (1993: 65-66), se hace una serie de preguntas sobre el porqué la gente va al cine, y a partir de esas preguntas, reflexiona. Se pregunta y se responde:

¿Por qué la gente va al cine? ¿Qué nos lleva a ese cuarto obscuro en donde durante dos horas observamos un juego de sombras sobre una pantalla? ila búsqueda del entretenimiento?, ¿La necesidad de una especie de droga? De hecho, existen en todo el mundo compañías y organismos dedicados al entretenimiento que explotan el cine y la televisión y muchos otros tipos de espectáculos. Nuestro punto de partida, sin embargo, no debería ser ése, sino los principios esenciales del cine, los cuales tienen que ver con la necesidad humana de conocer $y$ dominar el mundo. Creo que el thempo es la razón por la que una persona va normalmente al cine: por el tiempo pasado, perdido o aún no vivido. Acude al cine para obtener una cierta experiencia vital, ya que el cine, como ningún otro arte, amplia, acrecienta y concentra la experiencia de una persona -y no sólo la acrecienta, sino que la amplía significativamente-. Ése es el poder del cine: las "estrellas", los argumentos y el entretenimiento no tienen nada que ver con él.

Sí, pero no. Hay algo de enorme razón en las reflexiones de Andrei Tarkovski: el tiempo que se convierte en una experiencia vital por medio del cual permite expandir su conocimiento sobre el mundo, sobre su 
mundo. Pero también hay otras cosas que habría que considerar. Asimismo, hay algo del entretenimiento que no es posible soslayar, y así como esa necesidad, esa especie de droga que se convierte en afición, catarsis, liberación, redención. Y, sí, los argumentos y las estrellas tienen algo que ver con la experiencia vital.

El tiempo y la memoria. El tiempo exterior, histórico, y la memoria personal, por medio de los cuales, y a través del cine, se experimenta un mundo más amplio, externo e interno y se asimilan, adquieren y configuran sentidos sobre el mundo, la vida, la experiencia y la misma memoria. También, habría que agregar otro elemento más: la presencia de la memoria histórica que da la experiencia social. Es decir, el cine es además un discurso que "articula la memoria de un grupo y en el que se dicen las prácticas. Un modo de decir que no sólo habla de, sino que materializa unas maneras de hacer" (Martín Barbero, 1989: 111), una mediación histórica donde se desarrolla, a partir de sus contextos sociohistóricos, o de sus matrices históricas y culturales, una sensibilidad que se configura como manera subjetiva y objetiva de experimentar lo social, una estructura de sentimiento a partir de la cual se vive en sociedad y se crean los marcos subjetivos, el centro desde donde todo lo que se vive y se experimenta cobra forma sensible, pero también social. A través de la experiencia individual y social se genera una forma energética y emocional por medio de la cual ciertas situaciones, objetos, emociones, y sentimientos quedan suspendidos y se activan por distintas vías y circunstancias. La memoria es una de ellas, una memoria que fluye y se adhiere a la manera en la que la sociedad, la cultura y el individuo han tornado espacios y temporalidades en marcos de referencia del pasado, pero también en los conectores con vivencias de otros momentos.

Así, pese a que los hombres y las mujeres que hablan sobre su experiencia con el cine la vivieron o la recuerdan no como lo más significativo o importante, mas sí con cierta importancia y significación para ciertas cosas, aspectos, circunstancias o momentos en sus biografias, a lo largo de su vida y de la interacción social asimilaron y adquirieron todo un universo de formas simb6licas, de experiencias sensibles y emotivas, de experiencias individuales y colectivas, donde algunas son más importantes que otras, unas se conectan más que otras con dimensiones más amplias, lejanas y continuas, y otras, no; donde algunas se adhieren a formas representativas e institucionales de ver y evaluar el cine, pero otras, no, sino que corren por derroteros más cercanos que no tienen visos marcadamente institucionales.

Es decir, a partir de una experiencia durante años con el cine, hombres $y$ mujeres fueron conformando un mundo en su interioridad, que su memoria hace emerger. Si bien en la mayoría de los casos es visto como un mero hecho de entretenimiento y diversión, hay un trasfondo más profundo que es posible observar en la forma como esa experiencia se 
entreteje con dimensiones sociales e individuales más amplias y profundas en todo el mundo del cine que se instal6 en su experiencia, en su interior, así como en el modo en el que esto se hizo a través de toda una generación de personas que pertenecen a grupos sociales similares, y en la manera en la que conformó a distintas generaciones, en algunos de los trazos que los conectan, y en otros que los desconectan.

Por ello, existen elementos en las experiencias que son parte de una generación, pero hay otros que son parte de varias generaciones, que se mantienen y conservan y les dicen cosas con intensidad, aunque quizá con otros significados y maneras. Asimismo, hay coincidencias importantes y elementos comunes entre todos, pero también diferencias esenciales tanto desde las perspectivas en las que lo vivieron las mujeres respecto a los hombres como entre ellos mismos debido a la trayectoria y al contexto familiar e individual.

Si bien la mayoría vio una enorme cantidad de películas, pues era casi una obligación social ir al cine cada domingo, o jueves y domingo, no todas se quedaron en su memoria ni las disfrutaban de la misma manera. Algunas constituyen un océano de películas que se pierden en la negrura de su memoria, y otras emergen a partir más bien de sus perfiles generales, de los géneros de películas que se tornan en dispositivos de conformación de una preferencia, un gusto, una implicación emocional y sensible, y un "lugar" desde "el que se lee y se mira, se descifra y comprende el sentido de un relato" (Martín Barbero, 1989: 113). Otras se recuerdan gracias a los actores de quienes su presencia habla no solo de una ideología, sino de un modelo y de una experiencia que posibilita y se extiende a través del tipo de películas en las cuales actuaban. Otras se evocan como películas concretas, específicas, unas por ser referentes obligados para la época, la historia del cine, o para la experiencia de los sujetos de un periodo que en ocasiones se extiende a otras generaciones, y otras más, por ser películas o actores que no necesariamente eran las y los del gusto generalizado, pero a las o los que, por algo, se les dio una implicación y se conservaron en la memoria y en la vida emocional de los espectadores.

A partir de ello, hay un sentido que adquiere lo que era el cine para los espectadores y lo que veían que era para la ciudad o para gente de su condición genérica o época, que lo mismo se manifiesta a través de una actitud, un comportamiento, o un estilo de vida, que como una sensación $o$ expectativa.

\section{El imperio de los sentimientos}

Quizá habría dos elementos que eran comunes en la experiencia de cada individuo, grupo social y la ciudad. Estos dos elementos surgen a partir de lo expresado por uno de los hombres: 
El cine es un espacio al mismo tiempo de reunión y de fuga. En términos muy generales sería, diversión, hacer algo distinto, pero, ya dentro del espacio cinematográfico es un lugar de reunión. Puede ser esto muy claro porque te pasan (sic) la película en televisión y la gente tiende a ir al cine si quiere porque hay salir. Si tú te quedas a ver la película en tu casa, tú no te mueves espacialmente, estás en u casa, entonces se siente la necesidad de ir a otros espacios, aunque sea película que la puedes ver en tu casa. Es una concepción del mundo de cómo te estás moviendo, si implica salir, trasladarte y otro lugar donde vas a ver el espectáculo, con otras personas, te vas a saludar, vas a participar en un espectáculo y mientras en tu casa no participas. Es una relación más personalizada, individualizada; aunque te compraras una pantallota del mismo tamaño del cine en tu casa, la actitud de ver cine no sería la misma (LEH9).

En esta reflexión, el hombre hace una síntesis de cómo hombres y mujeres evalúan lo que era la experiencia del cine para sus vidas o para la ciudad de León. y en ese punto hay una diferencia importante en la manera como la evalúan los hombres y las mujeres, así como lo hacen las diferentes generaciones, principalmente entre los hombres. Comencemos con los hombres.

Los hombres mayores ven su relación con el cine, en el pasado y en el presente, como una manera de divertirse, de entretenerse, no más. Uno de ellos expresa que ni en su familia ni en el círculo en el que se movía era una obligación social ni un referente, aunque no era algo de lo cual se privara, sino que asistía para disfrutar de alguna cosa que le llamara la atención. Expresa:

Sí era importante, pero no era fundamental, como que tenías [sic] la posibilidad de asistir; en ocasiones traían buenas películas y todo mundo ibamos a ver buenas películas. Pero así que tú dijeras "es una costumbre que voy al cine", no sé, una o dos veces por semana; no era mucho, no había mucha afición al cine, no sé si era porque el repertorio que había era muy pobre o a lo mejor era que así fue como yo me eduque. Nosotros íbamos al cine cuando había algo que valiera la pena, pero yo me podía pasar meses sin pararme en el cine y no todo el mundo era muy cinero (LEH2).

Una visión radicalmente distinta es la de un hombre que admite que el mundo del cine era muy importante para él, e incluso, se llega a definir como un "filmívoro":

Es mi vida fundamental, porque en eso soy una categoría más allá de cinéfilo, es así "filmívoro", el cine es así parte sustancial de mi vida, a lo mejor por una tendencia neurótica, irme a una posibilidad de construir otra realidad, como una forma de habitar un espacio donde construir otra realidad, para mi era una realidad el cine y lo sigue siendo a la fecha. Más que del cine de aquella época, lo 
que añoro es yo en aquella época porque el cine abrió una posibilidad a hacer imaginación (sicl, y salir del cine era salir a jugar sobre lo que uno había visto en el cine (LEH9).

Este hombre se torna más reflexivo sobre su experiencia con el cine y declara que le ayudo a construir mundos imaginarios, así como que le da improntas particulares a la manera en la que se relaciona imaginariamente con ciertas realidades concretas. La diferencia de este hombre con otros, es que le ha dado significación a eventos minúsculos a un nivel de globalidad en ciertas cosas que le dejaba el cine de niño y de adulto.

Los hombres más jóvenes recordarán otras relaciones con el cine, lo hacen más íntimo y es más fácil para ellos expresar algunos elementos que les dejaba, o lo que percibían que sucedía con ellos o en la ciudad. Por un lado, hay más reflexividad sobre la relación, pero también es más notorio que el cine se extendió más allá de una mera imitación de las películas por medio del juego a una confección en su manera de ser y actuar a través de la moda y ciertos comportamientos.

El cine era más una cohesión social, una integración social y afectiva, un referente de renovar redes sociales, pertenencias y ubicación social que, si bien no dejaban de asimilar y disfrutar las películas, éstas se đaban más por el hecho de divertirse grupalmente. Era una diversión y una reunión social. Fuga y reunión colectiva.

\section{Vive y deja vivir}

Si bien uno de los primeros ejemplos de la manera como se ve que las películas ejercían una influencia en la infancia era a través de imitar lo que se veía, puede ser pensado con aquella visión de Freud sobre el juego infantil, que es la creación de un mundo fantástico, regido por el deseo de ser adulto (Freud, 1972: 11), habría que ver dos aspectos a partir de ello: el juego que se realiza imitando a los personajes y las tramas de las películas que son un constructo histórico y cultural de lo que es divertirse, y los sentidos que se desarrollan en ese juego. La diversión se materializa no sólo en el plano imaginario, sino que a partir de cómo se configura éste, se materializa en una forma de jugar, que es un perfil de las maneras como se desea ser adulto. Y cuando se es adulto, los objetos del juego desaparecen, pero no así el mundo del deseo y de la fantasía, que pueden trasladarse a otros objetos, como las enseñanzas o los comportamientos de adolescentes o adultos y las indumentarias y formas de actuar que pueden apropiarse como un modo de representar ese mundo imaginario y simbólico sin ser un juego, pero sí un estilo de vida y como símbolos de identificación y diferenciación. 
Uno de los hombres expresa lo que veía que ocurría con gente de su edad en su relación con el cine:

Había ciertos comportamientos sociales y estereotipos que se permitian después; desde el tipo que quería ser James Bond, tal vez no tanto en el comportamiento erótico sexual, pero sí en el comportamiento del coche o que le pongan ese tipo de cosas [sicl. En las mujeres era más notorio, o sea la moda, el vestirse. De mis compañeros andaban asi vestidos en prepa; ese tipo de películas a lo mejor fueron toda la parte psicodélica o hippie, el pelo largo, traíamos la greña larga, pantalón de campana, las camisas que se pusieron de moda que ahora están otra vez, de círculos (sicl. Ese comportamiento yo creo que sí, era muy notable que provenía del cine, que provenía de la televisión en los j6venes (LEH8).

De este modo, varias de las películas que se veían no sólo cobraban vida en la imaginación de los jóvenes, sino en su forma por ser, que se extendia y se convertía en un referente social y de época para los hombres como forma de pertenecer a un grupo y una forma de interactuar. Si bien a muchos el cine les podía significar un mero pasatiempo, la influencia de ciertas películas en ellos o en su entorno, terminaba de ser un hecho y un medio de pertenencia o integracion.

En el caso de las mujeres, sucede de una manera similar a la de los hombres en el sentido de que las mujeres mayores tienden a ver de un modo su relación con el cine y las más jovenes a concretizarla en la manera como małs cotidianamente se extendía en ellas mediante modelos de imitación y la estilización del cuerpo por medio de la moda. Los hombres mayores hablaban de diversion y entretenimiento. Las mujeres mayores lo dirán de otra manera: socializar y abrir el mundo.

Una de estas mujeres expresa en dos momentos la importancia del cine en su adolescencia. Por un lado, la fuga, por el otro, la reunión. Expresa:

Veía como una forma de socializar el hecho de ir al cine, y las películas en sí pues era una manera de distraer, lo que era la cotidianeidad de ver lo que sucedía [sic] en otros lados, de aspirar a ciertas maneras de ser tal vez, a que cambiara un poco la manera tan cerrada de la sociedad leonesa porque lo veias en el cine y una cierta liberalidad en otros países que no se daba en México. Incluso en la película de Los Caifanes, como que ahí se muestran las dos caras o varias caras de este tipo de sociedad, en donde Enrique Álvarez Félix es el actor principal, él es el futuro esposo de Julissa, es el prototipo de la sociedad de determinado nivel socioeconómico del momento, como que en su personaje se reúne todo esto que te estoy diciendo del deber ser, del qué dirán, de no te juntes con los nacos, en el ir con los nacos era algo de diversión era como snob (IrM3).

El cine era una forma de socializar, pero también un espacio de movilidad y apertura ante el mundo cerrado que encontraban en la 
ciudad, y a diferencia de los espacios a donde podían acudir y moverse con libertad, que era un mundo con pocas opciones para ellas, el mundo del cine les presenta otra posibilidad: ampliar visiones, vivir otros mundos. La socialización y el aprendizaje, otra manera de ver la fusión y la reunión, implicaba varias experiencias. La primera: el mundo se abre. Una mujer lo dice:

Me abrió mucho al mundo; primero que nada, te das cuenta $(\mathrm{sic} /$ de que existen otros mundos, que existen otras ideologías. Lo gracioso es que en el momento en el que lo estás viviendo no lo crees, digo no sientes, pero a parte del tiempo en ese momento que analizo, creo que sí, como que sí te abre un poquito el panorama. Por ejemplo, en mi caso no nada más existe León, en mi época no había universidades en León, las mujeres estudiaban en la Normal, Enfermería, pues creo que nada más y la que quería estudiar alguna carrera se tenía que ir a México o a Guanajuato, no era sencillo (LEM2).

La liberación no es nada más por el hecho de vivir mundos imaginarios y confrontar con su realidad: se debe a que algo que ven en ese mundo "rosa" de las películas que les gusta, a través de las actrices con las que se identifican, les otorga modelos de ser, por un lado en el sentido estético y corporal, pero, también, en las maneras como las ven actuar y lo que ven que expresan, sienten y aspiran. No sólo fue el cambio de modelos, de discursos cinematográficos, de la cultura en general y las transformaciones de la ciudad que a finales de los sesenta y a principios de los setenta se dieron en algunos elementos donde esos modelos podian tener algunos cauces y manifestaciones más allá de la moda, sino la posibilidad de que el cine, además de todo lo dicho, fuera un instrumento claro de reflexividad que conllevaba una visión ideologica e intelectual en estas mujeres. Una de las más jóvenes señala:

Para mí fue un elemento de formación muy importante, me hizo reflexionar sobre muchos aspectos culturales, y afectivos; como que me abrí muchisimo el panorama, era como el internet de ahora, conocías otras culturas, te metías a pensar [sic], a ponerte en el lugar de otra gente, emocionalmente vivías cosas que tú no podias asimilar de otra manera, era también como llegar a la literatura y al teatro de una forma más rápida, más digestiva, más digerible más rápidamente tambienn... A muchos de mis amigos que eran como de extrema derecha, yo les platicaba del cine y les decía lo que aprendia del cine, y me decían: "es que, cómo puedes tí aprender de eso", y ellos decían, "es que eso es pornografia". Depende de la mirada con que tú la veas, entonces para mí fue como un momento ideológico muy emocionante y cultural para cómo rescatarme también hacia la vida intelectual desde lo afectivo, porque ibas y te conectabas con ideas /sicl, con pensamientos, con formas de ver la vida que en un pueblo chico no se daban, porque León era un pueblo chico, ahora es una ciudad media, pero antes era un pueblo 
chiquito, en donde todo el mundo se criticaba, donde era dificil tener ideas más libres que en el teatro si te dejaba como observar, como menos represión, entonces era, sí fue muy importante para mi vida esto [sic] (LEM9).

Para las mujeres más jóvenes, el cine no sólo fue un aparato cultural y cognitivo, sino una posibilidad de asumir una perspectiva para ver el mundo y actuar en él. El mundo y su subjetividad se ha ido tornando relacional (Gergen, 1997) y el cine ha comenzado a actuar en ellas con otras perspectivas.

\section{Queremos tanto a Glenda}

Tarkovski expresaba que lo importante para el público era la experiencia del tiempo que se daba a partir de las películas. Si esa experiencia se considera como un rito continuo para ingresar a un mundo social, a un grupo afectivo, a un modo de vivir y acceder a realidades varias, la experiencia de los leoneses habla algo de ello. Tarkovski no veía la importancia de los argumentos y de las "estrellas". Al parecer, los leoneses sí, ya que fue sobre todo por medio de ellos que se conectaron con esa experiencia y podían atraerla a su vida. Es por ello que toca revisar cuáles fueron los artistas con los que se identificaban los hombres y las mujeres leoneses, pues además de que constituían un modo en el que el cine los implicaba afectivamente, eran portadores no sólo de ideología, sino de patrones de evaluación de películas, de modelos de vida, de tipos de masculinidad y femineidad que les atraian y que también eran constructos históricos y culturales. Es importante señalar las diferencias entre los hombres y las mujeres.

En el caso de los hombres, hay una tendencia generalizada a ver una ruptura en cuanto al tipo de actores y actrices con los cuales se identificaban o que les gustaban de alguna manera en particular. Veamos el caso de los hombres mayores.

Uno de los hombres mayores se expresa de la siguiente forma sobre el tipo de actores con los que se identificaba y con ello manifiesta un punto de vista generalizado:

Me llamaba la atención por la personalidad que ellos tenian y sobre todo era una personalidad que en el papel que se les daba en las películas era la misma, no era de que hoy salía de homosexual y que mañana salía de borracho, entonces gente como Gregory Peck, que ver una película de él era ver toda la certeza de que era una muy buena película [sic] (LEH1).

Mientras que de las actrices, su identificación es muy concreta, podría decirse que eran las mujeres que tendían a complementar el perfil masculino de los actores que le gustaban, por lo cual expresa: 
Habia varias, a mí siempre me han gustado las mujeres rubias, ellas tenían cierta característica que me gustaba, eran rubias, de tez blanca y no era la mujer exótica, sensual sino agradable, simpática y bella al mismo tiempo; por ejemplo, Diana Slate la que era o fue esposa de Tony Curtis, era una mujer que me gustaba mucho ver sus películas, de esta que parece venadita, Hawly Hedford, Deborah Ker, de esta chaparrita David Range [sic/ eran las artistas que yo recuerdo que me gustaba ver sus películas, Doris Day era otra (LEH1).

Mientras que el tipo de películas que le gustaban, tendian a ser:

Me gustaban las de guerra. Ahora me dan risa esas películas de guerra y analizadas, pues no comprendía cómo lo manipulaban a uno, la forma como presentaban las películas donde te demostraban el poderio del gringo, y ahora, como es posible que eso me gustara, pero era producto del momento [stcl. Las de los indios y vaqueros, otra de una situación más o menos lo mismo, sin saber que los malos eran a los que yo les iba. Luego, las comedias ligeras de artistas como Burt Lancaster, como Tony Curtis, como Gregory Peck, Tyron Powers, que eran novelas donde tenían otro prototipo que se perdió, tú sabias que el actor el primer actor siempre iba a ser el bueno, era incapaz de ser el villano, era un hombre respetuoso, poderoso y eso era lo que nos gustaba (LEH1).

A estos hombres les gustaban películas de acción, comedias ligeras, de suspenso y algunos dramas. Los actores que tienden a representar sus gustos son Tony Curtis, Rock Hudson, Gregory Peck, Burt Lancaster, John Wayne, Marcelo Mastroianni; mientras que en mujeres, Doris Day, Tayron Powers, Sofia Loren, entre otras.

En el caso de los hombres más jóvenes, pareciera que algunas de las tendencias de los gustos se conservan, pero que adquieren otros derroteros. Por un lado, su larga experiencia con las matinés donde entran en contacto con películas mexicanas de otras décadas, pero, por otro, hay una serie de renovaciones en la producción del cine estadounidense, la lenta desaparición de películas italianas, alemanas, y francesas, la aparición de una serie de películas juveniles tanto mexicanas como españolas, y la crisis del cine mexicano durante la década de los setenta que al tiempo que reduce su producción de manera sensible; presenta un cambio de temáticas y géneros respecto a lo que se hacia en décadas anteriores. Con ello, aparece un relevo de actores y actrices, tanto de los que emanaran del mismo cine, como de los que empiezan a destacar en la televisión. Uno de estos hombres habla acerca de toda una serie de películas que descubre y le van diciendo algo, películas mexicanas de los setenta:

Admiraba como director a Ripstein a partir del Castillo de la pureza, a Alberto Isacc, a quien me toca conocer porque era medio amigo de mi madre y era parte de su grupo de amigos [sic]. Alberto Isacc filma una película, Los días del amor, en 
donde entran como extra algunos de mis parientes y que comienza con una fotograf̌a de mi tío Laureano, que había sido gobernador de Colima, entonces había una relación más estrecha. $\mathrm{Y}$ esto me pone en contacto con la posibilidad que Isacc demuestra de hacer un cine autobiografico. Entonces, admiraba a Isacc y a otro cuate, lópez Moctezuma que a partir de un cuento de Poe, filma La mansión de la locura y que ahí quedo, no hizo nunca otra película. Despues, hizo otra película que se llamó Alucarda, con Tina Romero, pero que ya disminuyó muchísimo lo que uno había visto en La mansión de la locura. Lo mismo que para con Isaac, no vuelve a hacer otra cosa igual de bella que Los días del amor. Me llamaba mucho la atención lo que en ese entonces se llamaba el cine de vanguardia o la nueva ola del cine mexicano o el nuevo cine mexicano, cosas como El Apando, donde descubro a Cassals, que hasta la fecha creo que ha hecho lo mejor y es de los mejores en el cine mexicano; Cascabel era un peliculon. Admiraba mucho a Bonilla y a Sergio Jimenez, que eran así como los grandes actores. Sergio después de su trabajo con Ibáñez en Los Caffanes, se dedica a hacer otras cosas (LEH7).

$Y$ después de hablar acerca de esas películas que le impactaron, que le decían cosas, expresa que se dieron en un momento que significaba, porque lo buscaba, un cambio, que era lo que a él le atraía e implicaba, y que el cine era uno de los nodos por donde se manifestaba todo ese movimiento de transformación:

El cambio sintetizaba mucho el grito universitario, cuestiones de ecología, libertad, de querer cambiar al mundo precisamente y en este entonces esto hay que ligarlo con el propio discurso matizado por el echeverriato, hay que ser antiimperialistas, hay que volver al nacionalismo mexicano, hay que dejar la dependencia, hay que convertirnos en líderes del Tercer Mundo. Todo esto lo ves reflejado en el cine y lo ves reflejado en la música y lo ves reflejado en las expresiones culturales (LEH7).

Si bien la mayoría de los hombres de esa generación tiende a tener una preferencia por películas de acción, comedias y dramas, como los mayores, se da en un contexto diferente. En primer lugar, hay una vinculación con las películas mexicanas, principalmente con algunas de aventuras y cómicas, así como con algunas de las películas juveniles. Otro vínculo será con aquellas películas mexicanas que se dieron en los setenta, entre aquellas que conservan un dejo de las películas juveniles de los sesenta, y las que se darán a finales de esa década donde comienzan a aparecer las ficheras y una serie de comedias picarescas por la presencia de vedettes, cabareteras y actores con dejos de prototipos sexuales masculinos, una secuela que comienza con Mauricio Garcés, y en donde se manejan situaciones eróticas rodeadas de cierta comicidad, pero también algunas películas mexicanas que buscaban una expresión cinematográfica distinta, más crítica y profunda, menos comercial. 
Asimismo, se puede observar que con la aparición de las películas con manifestaciones de los jóvenes de la época, a partir de Semilla de maldad, y las posteriores que se desarrollan y cuyos símbolos serán personajes como James Dean y Elvis Presley, hay la tendencia hacia una juvenilización de los gustos de los hombres. $\mathrm{Si}$ partimos de que los personajes que les agradaban o con los que se identificaban eran hombres con personalidad recia y varonil al estilo Tony Curtis, Rock Hudson, John Wayne, Marcelo Mastroianni, actores como los de toda la saga mexicana de películas juveniles, o Dustin Hoffman, vemos que las personalidades y modelos de los actores cambian y, por un lado, son imágenes y retratos de un mundo juvenil de clase media, ligera, pero que manifiestan esa condición, esas ganas de ser joven, y algunas de las problemáticas y circunstancias que los envuelven dentro de un mundo nuevo que llega y que marca una diferencia y distancia con lo adulto, y, por el otro, porque son manifestaciones de aquellos mundos sórdidos, conflictivos, y ambiguos que ellos mismos vivían o vislumbraban como la vida de esos momentos.

\section{Lo que el viento se llevó}

En el caso de las mujeres, el panorama es similar, aunque con algunas diferencias. Es similar en el sentido de que hay la tendencia a una predilección general sobre determinado tipo de películas, a identificarse con ciertos actores y actrices, $\mathrm{y}$ a tener una cierta implicación con determinadas películas que les dicen más en lo personal.

La diferencia estará más por el lado del tipo de películas que no son nada más un cambio de gusto y de trama, sino del lugar y circunstancias desde donde son "leídas", y de lo que representan esas distancias de las lecturas respecto a las de los hombres. Asimismo, una diferencia importante será que hay más continuidad en preservar un tipo de personalidad masculina como ideal, con sus renovaciones generacionales de los actores, mientras que en el caso de las actrices con las que se tienden a identificar las mujeres más jóvenes es donde se comienzan a dar algunas rupturas respecto a las generaciones de mujeres mayores.

Veamos el caso de las mujeres mayores: una de las mujeres de este grupo hizo el siguiente comentario sobre el tipo de películas que le gustaba ver, donde se combinan actores, actrices, tendencias, y tramas:

Me gustaba ver a Robert Taylor, me gustaba ver a Tyron Power, me gustaba ver a Charlton Heston, me gustaba ver a Sean Connery.

Ya cuando estaba yo más grande, películas del género romántico era lo que me gustaba ver a mí. No me gustaba ver películas de guerra, ni cosas que me lastimaran, pero a veces que era la mejor película y la clasificación estaba para 
poder ir, pues te ibas a ver una película como Quo Vadis? (sicl, con Deborah Ker y Robert Tylor. Peter Stenov, que hizo un papelazo de Nerón, me encant6. Son películas que se te quedan pegadas. Los amantes deben aprender, con Susan Pretcher, jqué película más hermosa con unas vistas de Roma!; Las siete colinas de Roma con Mario Lanza y Marizza Lazio. Tamblén por ese tiempo vi películas históricas, de la época de los césares, Calígula, tumbien me impresionó mucho, Cleopatra con Elizabeth Taylor. Liz Taylor me encantaba, la primera película que vi de Liz Taylor fue Juego de jutentud, cuando yo tenía 12 años en el colegio y las madres ponían la mano así cuando le dio el beso a Micky Runney porque jormo ibas a ver besos!, las madres te ponían el cinito del colegio, jolvídate! Otra que vi, Mañana es demastado tarde, fue una película muy bonita italiana con Piere Angeli, iqué película tan más bonita! (IFM1).

Esta mujer pone sobre la mesa varias de las tendencias de lo que a ella, y a la mayoría de las mujeres les gustaba, donde hay una tendencia hacia las películas históricas, las bíblicas, pero, principalmente las románticas, ya que, según ella, le "gustaban las películas, románticas, románticas, siempre con un fondo, un sentido del amor, pero del amor bonito y de la realización" (LEM1). Otra mujer de este grupo comienza hablando de un tipo de películas que le gustaban, que son radicalmente distintas a las de las mujeres anteriores:

Iba frecuentemente al cine Vera; a mi mamá le gustaban, Bella de noche y Lolita, pero en aquel entonces no era bien visto que uno fuera a ver ese tipo de películas porque trataban de temas de sexo muy fuertes o conductas de la mujer como no aceptadas socialmente en el cine, en otros medios sí, pero aquí, no; entonces, como que estabas captando otras formas de comportamiento que no eran aceptadas socialmente. A mí me gustaban, siempre me han gustado las escenas fuertes que traten temas candentes que po se hablen abiertamente en la sociedad. En el medio en el que yo me desenvolvía no era bien aceptado que una mujer viera esas películas, era malísimo. Por lo mismo que te digo, que la sociedad fijaba las normas y querían que la gente las aceptara, había una regla implícita: las muchachas decentes no ven eso, y menos con su mamá, a lo mejor a escondidas te podías ir, pero con tu mamá, no. Pues quizás digamos que éramos cómplices de ir al cine y nos divertíamos muchísimo (LEM4).

Y cuando habla de las películas que más le gustaban e impresionaron, aparece otro escenario:

Me llama mucho la historia, de manera muy aficionada, la historia. Veíamos muchas de tipo Sissi, de Alejandra y Nicolás, de las reinas, reina Victoria, de los Tres Mosqueteros, en fin ese tipo de películas. No recuerdo alguna en especial asi, bueno por ejemplo Lo que el viento se llevó. Lo que el viento se llevó, me encantó, me gustó muchísimo, Ana de los mil dias, pero esas eran de las decentes, Enrique 
$V I I$, bueno, yo veía muchísimas de la Segunda Guerra Mundial, Tajate, El árabe, me encantaba la película $E l$ árabe. Pero también ya había leido la novela, entonces vas y ves la película [sic] porque ya la novela te gustó (LEM4).

Con esta otra cantera de películas, la mujer manifiesta una tendencia similar a la de las otras mujeres: un gusto por las películas históricas y románticas, pero la diferencia es que le gustan de manera explícita aquellas que son intentos de confrontación con una realidad que oprime y limita, actos de rebeldia que ve en la pantalla y que la misma mujer hacia al ir a ver algunas que eran condenadas por el grueso de la sociedad. Más que el sacrificio, el encuentro, el acto de insubordinación.

Por su parte, una mujer más joven y que vive en una etapa en la transición de las películas que llegaban a la ciudad, expresa:

Me acuerdo de que estaban de moda en ese entonces las artistas españolas, Rocío Dúrcal por ejemplo, que empezaba con sus películas, unas gemelas que se llamaban Pili y Mili, Joselito, un niño que cantaba; como que había en esa época películas de nin̄os y de jovencitos artistas, entonces las películas españolas [sicl. A mí de niña me encantaban las caricaturas o las películas de aventuras, o las de tipo King Kong. Del cine norteamericano me acuerdo de las películas de Doris Day que eran así como muy, muy bien recibidas ack, tenian mucho público. Y de cine mexicano yo realmente creo que no eran como mucho del gusto del público, porque eran las películas de Marga Lopez, de Pedro Infante, de Arturo de Córdoba, de repente las veía uno, pero no eran como las que a uno de adolescente le gustaban, sino más bien a uno le gustaban las de Rocío Dúrcal, de Joselito, de toda una serie de películas. Me acuerdo de Sissi Emperatriz, Sissi no sé qué, que eran unas películas donde trataban la vida de la emperatriz Isabel de Austria, todo el mundo queríamos ser Sissi, son así las que ubico de esa época... Por ejemplo, de los norteamericanos eran Doris Day, Rock Hudson, estaban en su mera época, sobre todo películas de alguna manera musicales, y las que te digo que venian así en cascada (sicl. Las de Sarita Montiel por supuesto, El altimo cuplê, ésas sí eran las pasionales, las otras eran muy blancas, Marisol, Pili y Mili, Rocío Dúrcal, pero cuando tenía por ahí como 16 años (IIPM).

La mujer expresa que las películas que la impresionaron fueron de acuerdo a su edad:

Como que hay muchas. También yo creo que depende de la época, como que hay películas que han respondido a diferentes momentos de mi vida y a diferentes contextos. Digamos, a principios de los sesenta o por ahí, así que ubico que me impactaban las películas, por ejemplo, de aventuras. Yo me acuerdo todo lo que fuera película de aventura o de ficción, a mí me llamaba mucho la atención. King Kong, mé acuerdo que de niña me impactó mucho; después, ya en otra década, en los setenta, digamos Jesucristo Super Estrella, por la música, por el tema, por 
todo. La de 2001 Odisea del espacio, como que también marcó otra época, otra visión. En el cine de los ochenta yo creo que estas películas posteriores a la guerra de Vietnam, por ejemplo la de Regreso a casa, estas películas que critican, que tienen todo un movimiento de crítica hacia la guerra y todo eso, entonces, como que esas a mí me gustaban mucho, me impactaban mucho (LEM5).

Por un lado, los primeros momentos de la experiencia cinematográfica de esta mujer son similares a las de las mujeres mayores. Un punto de coincidencia no sólo son ciertos tipos de temas de películas, sino actrices y películas muy concretas que parecían entrar en su mundo afectivo y ser un símbolo de la búsqueda de una autoidentidad, de una realidad deseada, como sería el caso de Sissi, o de Doris Day, y que en las mujeres menores se ampliará con una gama de actrices españolas, principalmente Marisol, que fungían como modelos, prototipos de ser y de vivir, una configuración afectiva que las impresionaba. Pero, por otro lado, se puede observar una ruptura, aquélla que proviene no sólo del paso a ser jóvenes, sino del entorno que les tocó vivir, mundial, nacional y local, y que se refleja en el tipo de películas que ven y les impactan, en el nuevo prototipo de mujeres que emanan de la pantalla, donde uno de los símbolos fue Jane Fonda, y que a su vez da pautas para observar los cambios en sus identidades, y las diferencias entre las subjetividades de las mujeres menores con las mayores.

Estos cambios se pueden ver a través de las preferencias de las mujeres, donde hay dos prototipos de ser mujer entre las cuales se mueven las identificaciones de ambas generaciones: de actrices que van de un prototipo a la Vivian Leight y Sofia Loren, a la de Tyron Powers y Doris Day, que se actualizarán posteriormente entre un vaivén de actrices que se identifican con Vanessa Redgrave, Liv Ulman, Jane Fonda, a Marisol, Rocío Dúrcal y Pili y Mili.

Sin duda, la experiencia de las mujeres leonesas con el cine parece estar trazada por márgenes un tanto diferentes a la de los hombres. Aunque hay un èspíritu de época y un contexto social similar, las dimensiones culturales las llevan por rumbos un tanto diferentes, tanto por las marcas como se les generó una imagen y una pauta de ser, como por lo que a ellas en particular el mundo del cine, cierto mundo del cine, les abria y les permitía vivir, sentir y experimentar. En parte de sus memorias con el cine es donde se puede apreciar la distancia que había en muchas con sus vidas, y las aspiraciones y expectativas subjetivas que vivían. Pareciera que mucho de lo que les decían de sus vidas se decantaba en algún momento, o entraba en otra dimensión, cuando estaban en contacto con cierta experiencia con el cine: la realidad parecía perder un sentido y quedar sujeta a un mero enunciado, mientras que las imágenes en el cine podían colmar algo que las rondaba y les abría nuevos sentidos. La experiencia de confrontar un mundo que parecía estar basado en 
una distancia, la de sus vidas, a un mundo que las fusionaba a algo (Fernández Chrislieb, 1993: 255 y ss).

También, es posible encontrar que entre las mujeres de las dos generaciones existe una serie de continuidades, más cercanas al mundo sentimental, que se desplegaba en la necesidad de una aspiración amorosa, sexual, cognitiva y social, mediante una serie de elementos que las agrupaba e identificaba, como la aspiración a una vida sentimental, a un prototipo de hombre, a un prototipo de mujer con destinos que se afirman por sus propias decisiones, que portan con orgullo y deleite un estilo de vida sustentado en todo aquello que por tradición se condenaba: moda, autos, casas, restaurantes, viajes, aventuras.

El mundo subjetivo de las mujeres estaba entrando a un mundo abierto y el cine, también.

\section{Conclusiones. Una realidad aparte}

Es dificil no dejar de ver y de reconocer que los medios de comunicación han creado un mundo autónomo, autorreferencial, principalmente a partir de su desarrollo como tecnologías de comunicación masiva. En ese punto, los medios de comunicación propician una vida social que se sostiene por sí misma sin la necesaria interacción de las personas, sin la intervención de espacios sociales de interrelación, espacios para que estén juntos los grupos sociales.

El cine es parte de un desarrollo tecnologico que se refiere a una fase histórica que se desarrolló hasta la década de los sesenta del siglo xx, más cercana al fenómeno de las industrias culturales, de la cultura de masas. Es a partir de ello que cobra su dimensión cultural: ser una de las principales instancias de la culcura de masas que posibilitó tanto la conformación de las primeras identidades internacionales populares, como discursos narrativos y estéticos de expresión e impacto profundos $\mathrm{y}$ exploratorios. No por nada es el cine en donde se edificaron las figuras mitológicas del siglo $\mathrm{xx}$, que poco han igualado el resto de los medios de comunicación. Pero, también, el cine inauguró de manera masiva y social una de las características actuales de los medios masivos de comunicación: la perspectiva para una observación de la realidad de segundo nivel porque debido a su mayor tendencia de ser un medio de entretenimiento mediante la conformación de relatos que se edifican a través de un reflejo de la realidad, o de relatos de realidades ficticias, de manera masiva permitía observar las observaciones de otros (directores, personajes, actores), y el modo como enfrentaban y resolvian sus vidas, tipificando, modelando diversos imaginarios que reelaboran los posibles mundos de las vidas cotidianas de los espectadores. La realidad dejó de ser estática para estar en continuo movimiento (Luhmann, 2000). 
Sin embargo, el cine fue una tecnología que pudo estar presente en los contextos sociales de los grupos sociales diversos y para asistir a él había que ir a ese espacio. Más que una tecnología que entraba a la vida familiar, que generaba discursos sobre la vida del hogar y sus circunstancias, como la televisión, el cine entró a la vida social y les hablaba tanto de la vida social como de la vida íntima.

Es por ello que la experiencia cinematografica de los hombres y las mujeres en la ciudad de León se puede ver desde esas dos perspectivas. El cine se integró a la vida social y era una manera de pertenecer a una comunidad social. Rito tradicional que, sin embargo, le agregaba la posibilidad de ser un espacio para encontrarse como jóvenes y entre jóvenes, y eso, como el mismo acto amoroso, tenía luces y sombras. El cine unía a una comunidad, no sólo como rito, sino a través de un sentimiento comunitario y de época, un mundo cognitivo y afectivo. En ese mundo propio de ir al cine, estaba la cultura local presente: el cine propiciaba la interrelación y se basaba en mucho en la presencia de los otros, a veces, de una manera más determinante que el mismo acto de ver cine. Es decir, la presencia y el desarrollo en el espacio social local le favoreció formas de estar.

Mediante la continua interrelación social se adquiere el conocimiento de una serie de competencias en las cuales los grupos sociales aprenden a manejar las distintas competencias, habilidades y conocimientos de lo que todos, y cada quien, ha de saber manejar en los contextos sociales. Es cuando se pone en funcionamiento parte de los procesos de socialización, los discursos socializantes, los ritos y las costumbres que actúan como horizontes de conocimiento, que se ejecutan en las interacciones sociales. $\mathrm{Y}$ es por ello que los contextos se constituyen a partir de las personas que interactúan, los distintos espacios de los contextos donde realizan determinadas cosas, en diferentes momentos y por diferentes objetivos. Los contextos, entonces, tienen una serie de definiciones acerca de las distintas situaciones que se comparten, mediadas por una serie de normatividades, sanciones, $\mathrm{y}$, asimismo, de las acciones y sentidos que les agregan los sujetos que intervienen (Erickson y Schultz, 2002). El cine, entonces, era un artefacto cultural que reunía a unos sujetos que buscan y conocen a un objeto, dentro de una comunidad, mediando las reglas de esa comunidad, la ubicación social de cada uno y las experiencias que se desarrollaban y se acumulaban a través de repetir la experiencia a lo largo del tiempo (Cole y Engeström, 2001).

Es por ello que en el contexto social, que era la sala de cine, los jóvenes y las mujeres portaban toda una serie de conocimientos que les permitían definir lo que ahí era posible encontrar. Pero, simultáneamente, lo que le agregaba el contexto específico de ser una sala cinematográfica, les permitía usarlo de determinada manera y se podía encontrar un vínculo con su mundo social, pero, también con su mundo íntimo. Es 
importante para ello el caso de las mujeres, pues no sólo era un espacio social ampliado de la ciudad, a donde iban para formar parte de un grupo, saber y reconocer quiénes eran, verse y saberse vistas, sino para poder realizar una vida sentimental y afectiva que no necesariamente se encontraba en otros espacios, $y$, asimismo, una educación sentimental que les permitía que el mundo se les abriera, al conocerlo y conocerse a sí mismas.

Así, el cine estaba presente, también, de otra manera: como reflejo de to que se observaba. Los jovenes y las mujeres no podian sino comparar lo que veían con lo que vivían, y en ese reflejo había reacciones distintas, que iban desde reconocer que era una mera ficción, hasta ser una aspiración y un impulso por modificar formas de vida, de pensar y de sentir.

No es gratuito que las mujeres le den una denominación de segundo orden a la experiencia de ir al cine, pues el entretenimiento era, a su vez, una forma de conocimiento de otras culturas, formas de vida, su propia interioridad, $\mathrm{y}$, además, una forma de vincularse y formar una comunidad afectiva. $Y$ no es gratuito porque desde los marcos de sus vidas, de su cotidianeidad, de sus experiencias, miraban algo que no tenían, algo que faltaba, ratificaban que existían, que se podía sentir, y ser. Los hombres, no. Ven al hecho de ir al cine como un entretenimiento, un acto de-pasar el rato, de encontrarse con los amigos, buscar pareja, algo que solían hacer en otros espacios, pero donde lo particular era que ahí lo podían hacer y sentirse comunidad de hombres jóvenes.

La vida afectiva, amorosa, la sexualidad, la vida social se regenera a través de lo que les ha impreso como huella su cultura, pero alterándola, modificándola a través de lo que emerge con el nuevo mundo que observan, y que lentamente va apareciendo en su cotidianeidad (Morín, 2000). Un impulso que la modernidad ha ido generando y a la que han ido entrando por la vía de los imaginarios, que se integran en sus vidas como formas, estilos y aspiraciones de vida.

\section{Bibliografia}

Aceves, Jorge (1998), "La historia oral y de vida: del recurso técnico a la experiencia de investigación", en Jesús Galindo (coord.), Técnicas de investigación en sociedad, cultura y comunicación, CNCA/Addison Wesley Longman, México.

Appadurai, Arjun (2001), La modernización desbordada. Dimensiones culturales, Ediciones Trilce/Fondo de Cultura Económica Argentina, Argentina.

Castro, Ricardo (1996), "En búsqueda del significado: supuestos, alcances y limitaciones del análisis cualitativo", en I. Szasz y S. Lerner (comps.), Para comprender la subjetividad, El Colegio de México, México.

Cole, Michael y Engeström, Yrjö (2001), "Enfoque histórico-cultural de la cognición distribuidan, en Gavriel Salomon (comp.), Cogniciones distribuidas. Consideraciones psicologicas y educatiuas, Amorrortu, Buenos Aires. 
Darley, Andrew (2002), Cultura visual digilal. Espectaculo y nuevos géneros en los medios de comunicactón, Paidos, Barcelona.

Dick, Bernard (1981), Anatomía del film, Noema Editores, México.

Erickson, Frederick y Jeffrey Schultz (2002), "¿Cuándo tenemos un contexto? Algunos temas y métodos en el análisis de la competencia social", en $\mathbf{M}$. Cole, Y. Engeström y $\mathrm{O}$. Vásquez (comps.), Mente, cultura y actitidad. Escritos fundamentales sobre la cognición bumana comparada, Oxford University Press, México.

Featherstone, Mike (1992), "Global and local cultures", en J. Bird, B. Curtis. y T. Putman (eds.), Mapping the future. Local cultures, global cbange, Routlege, Londres.

Fernández Chrislieb, Pablo (1993), "El conocimiento encantado", en Arcbiptélago, núm. 13, Ediciones Archipiélago.

Freud, Sigmund (1972), Psicoanálisis aplicado y técnica psicoanalítica, Alianza Editorial, Madrid.

- (1981), El malestar en la cultura, 8² reimp., Alianza Editorial, Madrid.

(1983), Esquema del psicoanalisis y otros escritos de doctrina psicoanalitica, Alianza Editorial, Madrid.

Gergen, Keneth (1997), El yo saturado. Dilemas de identidad en el mundo contemporáneo, Paidós, Barcelona.

Giménez, Gilberto (2002), "Paradigmas de identidad", en A. Chihu (coord.), Sociología de la identidad, Miguel Ángel Porrúa/Uam-Iztapalapa, México.

Gitlin, Todd (2001), "La tersa utopía de Disney", en Letras Libres, año III, núm. 28, abril.

Gómez Vargas, Héctor (2003), "Sujeto del mundo, sujeto del conocimiento. O de las perspectivas para construir conocimiento en un mundo social complejo", en Texto Abierto, núm. 3, Universidad Iberoamericana León.

Hannerz, Ulf (1997), "Scenarios for peripheral cultures", en Anthony King (ed.), Culture, globalization and the world system, University of Minnesota Press, Estados Unidos.

Harvey, David (1992), "From space to place and back again: reflections on the condition of postmodernity", en J. Bird, B. Curtis y T. Putman (eds.), Mapping the future. Local cultures, global change, Routlege, Londres.

Jensen, Klaus Bruhn (1997), La semítica social de la comunicación de masas, Bosh, Barcelonà.

Johnson, Steven (2003), Sistemas emergentes. O quë tienen en comün bormigas, neuronas, ciudades o software, Turner/FCE, Madrid.

Lievrouw, Leah y Sonia Livingstone (eds.) (2002), Handbook of new media: social shaping and consecuences of ICT's, Sage, Londres.

Livingstone, Sonia (2002), Young people and new media, Sage, Londres. - (2003), The cbanging nature and uses of media literacy, MEDIAQLSE Electronic Working Papers, London School of Economics and Political Studies, Londres, núm. 4.

Lotman, Iuri (1996), La semísfera I. Semiótica de la cultura y del texto, Cátedra, Madrid.

Luhmann, Niklas (2000), La realidad de los medios de las masas, Anthropos/ Universidad Iberoamericana, Barcelona.

Lull, James (2000), Media, comunication, culture, $2^{2}$ ed., Polity Press. 
Lutz, Tom (2001), El llanto: bistoria cultural de las lágrimas, Taurus, México. Maffesoli, Michel (1993), El conocimiento ordinario. Compendio de sociología, FCE, México.

- _ (2001), El instante eterno. El retorno de to trágico en las sociedades posmodernas, Paidós, Barcelona.

- (2004), El nomadismo. Vagabundeos iniciáticos, FCE, México.

Martín Barbero, Jesús (1989), Procesas de comunicación y matrices de cultura. Itinerarios para salir de la razón dualista, Gustavo Gili, México.

Morín, Edgar (2000), Amor, poesia, sabiduría, Cooperativa Editorial Magisterio, Bogotá.

- (1966), El espiritu del tiempo, Taurus Editores, Madrid.

Navarro, Pablo (1994), El bolograma social. Una ontologia de la socialidad bumana, Siglo XXI, Madrid.

- (1995), "Hacia una teoría de la morfogénesis social". II Encuentro de Teoría Sociologica, Bilbao, España, en: http://www.netcom.es/pnavarro/Publicaciones/MorfogenesisSocial.html http:/www.netcom.es/pnavarro/Publicaciones/Morfogenesis Social.html

Robertson, Roland (1997), "Social Ttheory, cultural relativity and the problem of globality", en Anthony King (ed.) (1997), Culture, globalization and the world system, University of Minnesota Press, Estados Unidos.

Silvertone, Roger (1996), Televistón y vida cotidiana, Amorrortu, Buenos Aires.

Sinclair, John (2000), Televisión: comunicación global y regionalización, Paidos, Barcelona.

Steeg, Bent y Thomas Tufte (2001), "EEs necesario seguir un ritual? Explorando los usos sociales de los medios de comunicacion", en Estudios sobre las culturas contemporäneas, época II, vol. VII, núm. 13, Universidad de Colima.

Strauss, Anselm y Juliet Corbin, (1990), Basics of qualitative research. Grounded theory procedures and tecbniques, Sage, Londres.

Tarkovski, Andrei (1993), Esculpir el tiempo, UNAM/Centro Universitario de Estudios Cinematográficos, México.

Thompson, John (2000), "La transformación de la visibilidad", en Comunicación y Sociedad, núm. 38, Universidad de Guadalajara.

__ (1998), Los media y la modernidad. Una teoría de los medías de comunicación, Paidos, Barcelona.

(1993), "Historias de vida en el análisis del cambio social", en , J. M. Marinas, y C. Santamarina (eds.), La bistoria oral: métodos y experiencias, Debate, Madrid.

(1988), La voz del pasado. La bistoria oral, Edicions Alfons el Magnanim, España.

Tudor, Andrew (1975), Cine y comunicación social, Gustavo Gili, Barcelona.

Tufte, Thomas y Nilda Jacks (1998), "Local lives, global media, multiple identities.

Gaucho lives between chimarrao and cable television", en Anuario uNESCo, año $\mathbf{I 1}$, núm. 2. 